International Journal of Advanced Academic Research (Sciences, Technology and Engineering) | ISSN: 2488-9849

Journal DOI: 10.46654/ij.24889849

Vol. 6, Issue 10 (October, 2020)|www.ijaar.org

Article DOI: 10.46654/ij.24889849.e61011

\title{
STRUCTURAL FIRE ANALYSIS IN RESIDENTIAL AND COMMERCIAL BUILDINGS BASED ON IGNITION FREQUENCY, FIRE EXTINGUISHER PERFORMANCE, AND FIRE RISK INDEXES IN THE SOUTH-EAST ZONE OF NIGERIA FROM 2010 TO 2019
}

\author{
Adekunle A, Arowolo T.A, Omojola O. Olumide and Ibrahim H.D \\ Nigerian Building and Road Research Institute (NBRRI), \\ Federal Ministry of Science and Technology, Abuja, Nigeria. \\ Corresponding Author: casio2022002@gmail.com
}

\begin{abstract}
In Nigeria there is a marked lack of smoke alarms, fire blankets, clearly marked escape routes, fire extinguishers, and regular fire drills in most markets, offices, industrial buildings and blocks of residential flats. The exponential growth in cases of fire deaths, injuries, loss of properties in the South-east region is the motivating factors for this study. This study provides structural fire analysis in residential and commercial buildings based on ignition frequency, fire extinguisher performance, and fire risk indexes in the south-east zone of Nigeria from 2010 to 2019. Other parameters considered are risk of occupants, probability of fire suppression, efficiency of suppression, dependability of activation, probability of failure of firefighting by automatic extinction system, users, and fire service authorities. Results show that industrial buildings and warehouses are the leading structures with ignition frequency while open market and oil spillage terrain produced the least in terms of success in fire suppression. It was also gathered that single rooms were seen to be the most affected fire occurrences, fatalities, injuries, and naira loss in the region. In addition, cooking, heating, electrical breakdown and carelessness remain the leading causes of structures fire deaths, injuries, and Naira loss. Victims within the age of 21 to 60 were mostly affected in structure fires. For most residential structures, the kitchen emerged as the leading source of fires while the least is unclassified.
\end{abstract}

Keywords: Structure fires, risk indexes, ignition frequency, extinguisher performance. 


\section{Introduction}

The expression "residential", as utilized in fire information examinations, incorporates properties ordinarily referred to as "homes," regardless of whether one-, two-, or multifamily properties . Residential refers to a kind of property-regardless of whether it is a building or other sort of structure, or whether the property is simply the Land or Real Estate [1]. Residential properties likewise incorporate made housing, Hotels and motels, residential hotels, residences [2], helped living offices, just as shelter for special people ( mental patients, drug addicts, or convicts) that are intended to encourage their relocation to residential life. The term residential does exclude institutional properties, for example, prisons, nursing homes, adolescent consideration offices, or emergency clinics, however numerous individuals may live there for short or longer time frames. The expression "residential structures" refers to all fabricated Structures on residential Properties. Structures incorporate buildings [3] just as other non-building. By far, most of residential flames, deaths, and injuries happen in structures [4], and that is the place where counteraction events are focused on regularly. The expression "residential structures" refers to those residential structures that are enclosed, and where individuals invest most of their energy [5].

According to the "World Life Expectancy Report" in 2016, Nigeria ranked first in the World for deaths by fire [6]. The reason for this isn't the number of fires per se, but the absence of sensitization of fire prevention and escape techniques. On October 18th 1998, a pipeline explosion occurred in the community of Jesse [7]. Although the cause of the explosion has been debated, and the 1,082 recorded deaths earned the Jesse fire the distinction of being the deadliest pipeline explosion in Nigeria. Since then fire outbreaks in markets and urban areas of Nigeria have assumed alarming proportions. The causes of such fires include erratic power surges, illegal electrical connections, improper electrical fittings, substandard electrical materials, and use of indoor generators [8]. Effective fire safety management is based upon enforcing fire prevention legislation which will enforce the identification of all the potential risks associated with the various premises and effectively carry out an assessment of the adequacy of the measures provided. In addition to the problems of markets, offices and residential buildings, the fact that the bulk of petroleum products are transported across dilapidated roads means that fuel tanker explosions are becoming increasingly common. The most common factor in fire outbreaks in Nigeria is the poor responsiveness of the Nigeria Fire Service who have a well-earned reputation for habitually arriving late at the scene of the fire without sufficient equipment to solve the problem as seen in Figure 1.

Ill-equipped fire services [9] have been known to turn up at the scene without any water or fire suppressant chemicals! According to the Red Cross, once a raging fire has started people have only two minutes at most to make their escape [10]. Such escapes can be made easier by effective fire safety management [11]. With the recent outbreaks of fire in Abia, Onitsha and Enugu, it would appear as if it has become necessary to remind both State and Federal governments of their responsibility to protect not only lives but also property [12], [13]. From the Federal Inland Revenue Service Headquarters in Abuja to Balogun Market in Lagos, Onitsha Market in Anambra State to petrol tankers, fire outbreaks are becoming an uncontrollable phenomenon nationwide [14], [15], [16]. Indeed, there has been a substantial increase in the incidences of petrol tanker and market fires. Fire outbreak has been identified as the leading cause of loss of lives 
[17], [18] in Nigerian markets. In Benin City the famous Santana Market which recently suffered severe damage from fire is being relocated. In Anambra State, Onitsha is the nerve center of the State and the South-East in general. It is home to one of the largest markets in West Africa.

The State government rakes in billions in taxes from commercial activities in the City, yet the people of Onitsha have been relying on the Delta State Government Fire Service in Asaba [19]. Successive governments have not been able to use the internally generated revenue to provide adequate amenities [20], [21]. Roads are in a terrible condition and public utilities such as water and electricity [22], [23], [24] are virtually non-existent and despite the State Fire Service having been comatose for years, everybody is blaming them for non-responsiveness to the fire outbreaks [25], [26], [27] and distress calls. In truth, Fire Service responsiveness [28] can be compared to the sluggish response of the police when informed of armed robberies in progress. The underfunding of both agencies is a national disgrace. Most fire stations do not have the basic facilities [29], [30], [31], [32] let alone fire-fighting vehicles. The Nigerian Fire Service is one of those agencies which exist on paper only and on many occasions when help comes during a fire outbreak it comes from private organizations who lend their equipment [33], [34] to the public. The Fire Service Act of 1963 has not been reviewed since and as such the fire Service is the only statutory organization established by law to undertake or render services related to the outbreak of fire. All 36 States of the Federation along with the Federal Capital territory have fire services. There is a growing belief that since the government of the day doesn't consider funding [35], [36] the firefighting services to be a priority, they should privatize operations. The fact that the Federal Government is struggling to finance their deficit budget has been made clear by Minister of Works who has severally complained that there are insufficient funds to carry out much needed road repairs [37], [38], [39], even when such repairs have been budgeted for and announced publicly. The continued neglect of the fire service is a neglect of the citizenry [40], [41], [42].

The incessant cases of fatal fires in homes and public buildings in the South-east region resulting into loss of lives and property is the encouraging reason to conduct this study. Incessant fire outbreak in homes and industries in Nigeria leading to loss of lives and properties worth billions of dollars is on the increase. Many building residents do not have adequate knowledge of causes and prevention of fire outbreaks in their various buildings. This study provides adequate education and information that will raise awareness and cautiousness of occupants, employees and those responsible for activities in buildings. It will also assist occupants to take fire safety measures more seriously by detecting fires early enough. Findings from this study will provide information that will make it difficult for arsonists to carry out their mischievous acts in buildings. The field study allows an opportunity to understand the disaster scene, and the interviews generally will explore respondents' responsibilities and level of preparedness and challenges. The research study involves visiting and carrying out different tests at fire outbreak sites. Occupants of residential and public buildings were questioned. Doctors in various hospitals were interviewed concerning fire victims. Employees of relevant fire agencies were interviewed on past fire outbreaks they were involved in. Data on past fire outbreaks were obtained from relevant agencies. 


\subsection{Aim and Objectives}

The aim of this research work is to conduct structural fire analysis in residential and commercial buildings based on ignition frequency, fire extinguisher performance, and fire risk indexes in the south-east zone of Nigeria from 2010 to 2019 while the specific objectives are: to conduct fire risk analysis based on fatalities per year, money loss per year, risk of occupants death, and risk of property loss
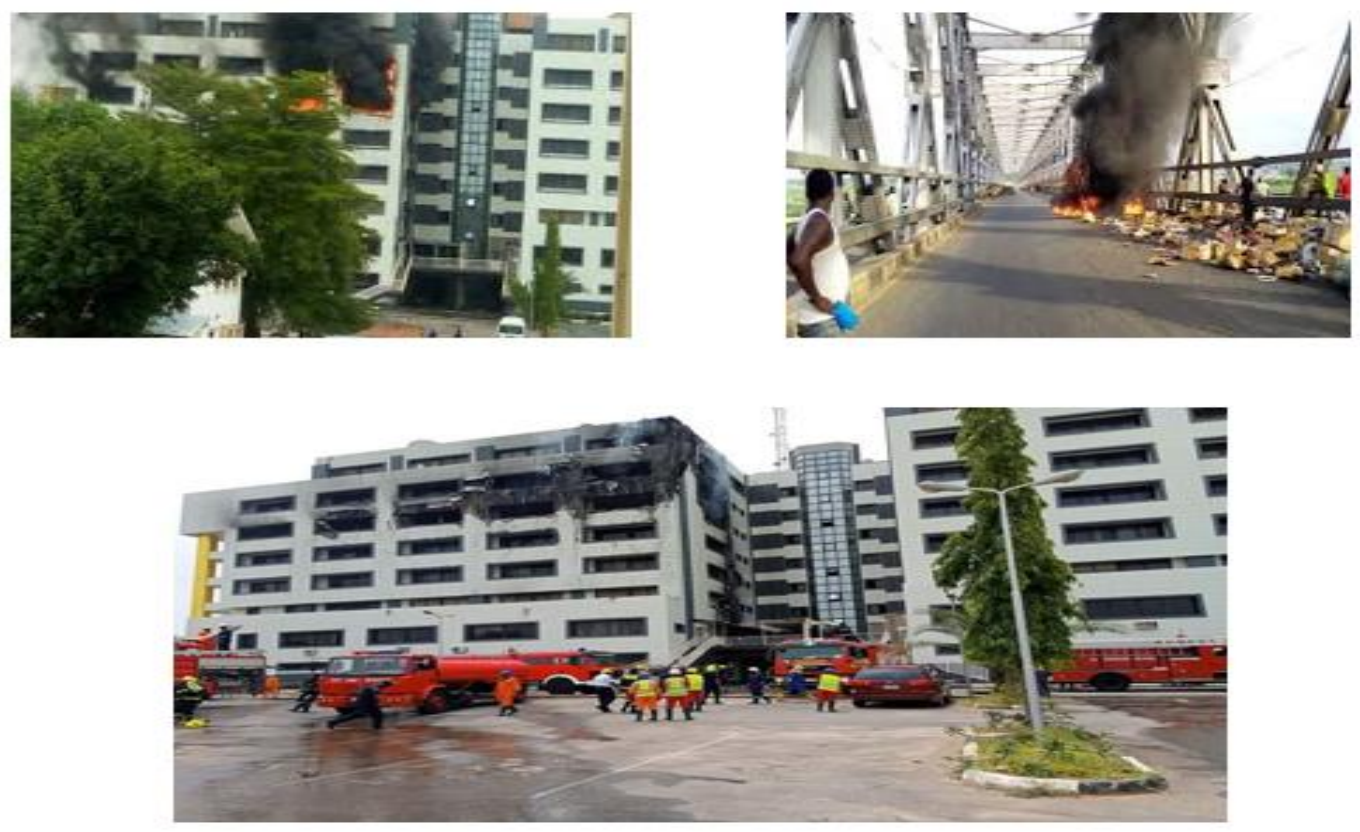

Figure1: Fire incidencies in South-east Nigeria

\subsection{The study area}

The South-east region in Nigeria is made up of five states namely Abia, Ebonyi, Anambra, Enugu, and Imo as shown in Figure 2. Abia is a state in the south eastern part of Nigeria. The capital is Umuahia, and the major commercial city is Aba, which was formerly a British colonial government outpost in the region, and is also one of the most populated areas in Nigeria. It is also the 5th most industrialized state in the country, and has the 4th highest index of human development in the country, with numerous economic activities and fast growing populations as recorded by the United Nations early 2018. The indigenous ethnic groups in Anambra state are the Igbo ( $99 \%$ of population) and small population of people who are bilingual, they live mainly in the north-western part of the state. Anambra is the eighth-most populated state in the Federal Republic of Nigeria and the second-most densely populated state in Nigeria after Lagos State. Ebonyi State is in South-eastern Nigeria. It is inhabited and populated primarily by the Igbo with the city of Abakaliki as its capital and largest city. It was one of the six states created in 1996 by the then federal military government of General Sani Abacha.

Enugu, usually referred to as Enugu State to distinguish it from the city of Enugu, is a state in South-eastern Nigeria, created in 1991 from part of the old Anambra State. Its capital and largest 
city is Enugu, from which the state derives its name. The average temperature in this city is cooler to mild (60 degrees Fahrenheit) in its cooler months and gets warmer to hot in its warmer months (upper 80 degrees Fahrenheit) and very good for outdoor activities with family and friends or just for personal leisure.

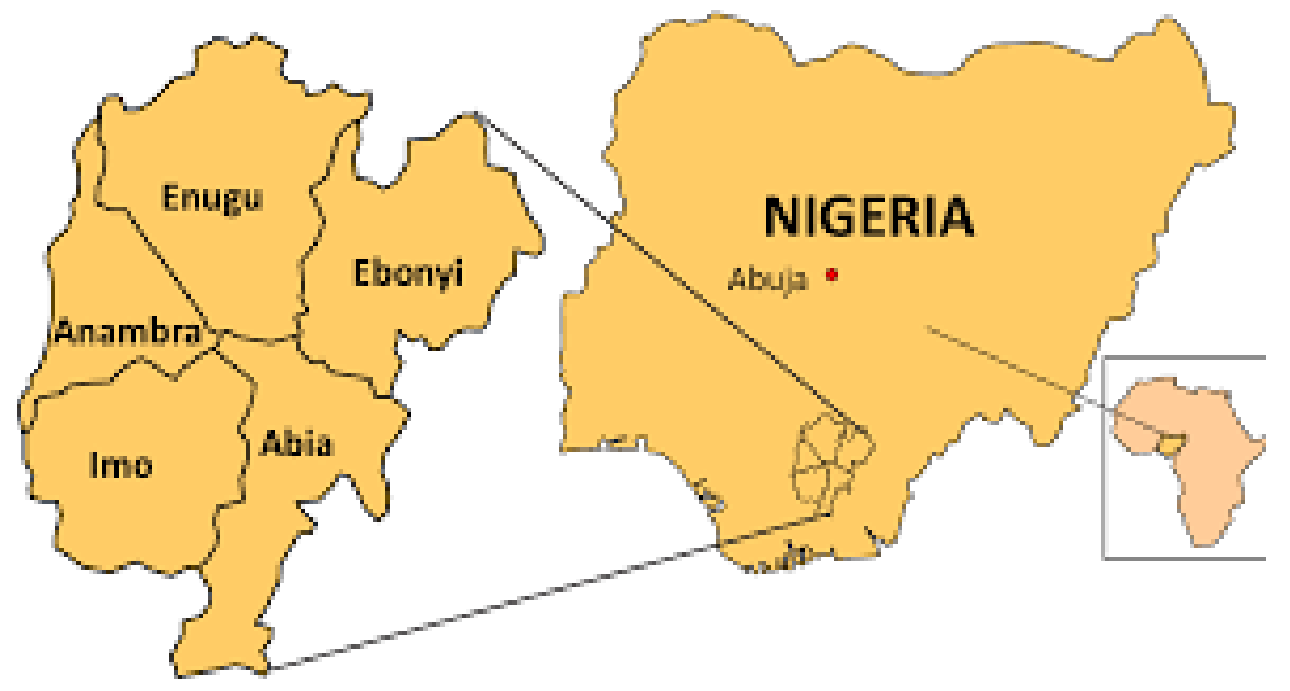

Figure 2: South-eastern, Nigeria Map

\subsubsection{Fatalities and Money loss per year}

Fire Risk is defined as the result of the Probability of Fire event and the outcome or degree of harm not out of the ordinary on the event of Fire. It is an element of three variables: loss of or damage to something that is esteemed (e.g., life, property, business consistency, legacy, nature, or a blend of these), the situation that may initiate the disaster or hurt, and a judgment about the likelihood that the disaster or damage will happen. Fire Risk is a weighted average of the Risk estimations of every situation, and it very well may be given the accompanying Equation 1, where Fire $_{\text {Risks }}$ represents fire risk (in terms of annual naira loss or fatality) $P O_{i}$ represents probability of fire occurrence situations $\mathrm{j}$, $\operatorname{Re} s_{i}$ represents results of situations $\mathrm{j}, \mathrm{n}$ represents total number of situations.

$$
\text { Fire }_{\text {Risks }}=\sum_{j}^{n} P O_{i} * \operatorname{Re} s_{i}
$$

\subsubsection{Fire Risks Index based on risk of occupants death}

This is employed to quantify building fire risks based on frequency of occurrence and deaths. The first step is to get important data about the target structure. Required data identified with the structure incorporates the size, area, development, fire security avoidance frameworks, the nature and likely condition of inhabitants and the data on fire office, for example, the separation to the target structure ought to be recognized. Identification of fire dangers is a cycle of perceiving that 
fire perils exist and defining their qualities. The area of the plan fire and the control of the structure throughout the hours, notwithstanding starting states of fire identification and alert hardware, and fire sprinklers must be recognized. A' fire situation cluster' is a subset of fire situations that takes after one another. It could gather the universe of conceivable fires into a reasonable number of situation subsets so all the components are available. A fire situation is a consecutive arrangement of fire occasions that are connected together by the achievement or disappointment of certain fire assurance frameworks or activities. A fire occasion is an event that is identified with fire commencement, or fire development, or smoke spread, or tenant conduct, or fire division reaction. Risk of occupants' death is given by Risk ${ }_{O D}$, frequency of occurrence of a developed accidental fire is given by Freq $_{\text {occurence }}$, and number of deaths due to fire incidents is given by $N_{\text {Deaths }}$

$$
\text { Risk }_{O D}=\text { Freq }_{\text {Occurence }} * N_{\text {Deaths }}
$$

\subsubsection{Fire Risks Index based on risk of property loss}

Considering the information gathered during fire inspection, three fire situation clusters can be viewed as imperative to help computations of recurrence and result; specifically a fire situation group, a fire programmed concealment situation cluster, and a conduct cluster. The fire situation cluster must specify all the components including plan fire curve and also numerous encompassing conditions of the fire, for example, compartment geometry and properties, measurements of the fire source room, the warm properties of the compartment limits. Risk of property loss is given by Risk $_{P L}$ and property loss due to fire incidents is given by Property ${ }_{L O S S}$

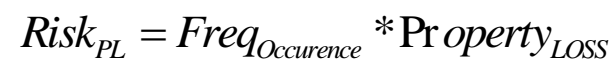

Plan fire curve implied that fire development rate and other specification, for example, the purpose of fire starting point, are required for a full interpretation [26]. The fire programmed concealment situation group depicts the cycle of fire suppression, either through the stifling of the fire or the control of the fire from additional advancement utilizing, for instance, information on development designing. Starting status of fire discovery and caution gear, fire sprinklers, smoke control frameworks all future included, and they could actuate distinctive fire concealment situations. The conduct situation group depicts the conduct of inhabitants because of the beginning of the fire and the intercession of fire and salvage administrations on account of building fires. The area, character qualities, information and experience, forces of perception and judgment, portability, mindfulness, jobs or duties in structures, and knowledge of the format of structures all influence tenants' practices. Central point influencing fire detachment intercession are mediation time, team size and fire fighting water assets.

\subsection{Estimation of Incidencies}

Based on three situation clusters proven in the process of fire risk analysis in most buildings, the frequency of occurrence of a developed accidental fire in a building with floor area B during the reference period of 12 months Freq $_{\text {Occurence }}$ is the product of the ignition frequency $I_{F}$, the 
probability of failure of firefighting by automatic extinction system $P F_{E X T}$, and the probability of failure of firefighting by users or fire department $P F_{\text {USERS }}$

$$
\text { Freq }_{\text {Occurence }}=I_{F} * P F_{E X T} * P F_{U S E R S}
$$

\subsection{Barrios Model}

To obtain adequate fire risk assessment, a dependable ignition frequency is a requirement which is largely based on the building class, while the ignition frequency within each building class depends on the floor area of the building. A more flexible practical form to model the dependence of the average annual probability of a fire starting in a building in the class under study on the floor area of the building, is a generalization of a model originally proposed by a French scientist called Barrios in 1835. Where, $I_{F}$ is ignition frequency of building with a floor area Xwithin a period of 12 months, Xrepresents the total floor area of the building, $\alpha_{1}, \alpha_{2}, \mathrm{P}$ and $\mathrm{Q}$ are coefficients.

$$
I_{F}=\alpha_{1} \mathrm{X}^{P}+\alpha_{2} \mathrm{X}^{Q}
$$

\subsection{Probability of failure of firefighting by automatic extinction system}

One way to control fire development is the use of automatic suppression systems, which either extinguish the fire or control it from further development. The probability of success of suppressing a fire depends on the reliability and effectiveness of the suppression system, and can be obtained from fire statistics. Dependability is the probability of sprinkler activation against huge fires, the efficiency is the probability of controlling fires once sprinkler is activated, and probability of accomplishment is the product of dependability and efficiency as shown in Table 1. The effectiveness of fire extinguishment can be modeled as a function of the ratio of the firefighter's intervention time to the flashover time

\subsection{Probability of failure of firefighting by users or fire department}

The probability of successful manual extinguishing was based on the fire accident statistics obtain within the region of consideration. The probability of accomplishment of fire department intervention largely depends on intervention time of fire department, availability of adequate response resources, and fire development in buildings. The intervention time is defined as the duration from the time of ignition of a fire to the time when the fire service commences fire extinguishment and rescue efforts. The quicker the intervention time, the less severe is the fire, and the smaller the effort that is required to fight the fire and to rescue any trapped occupants. The statistics obtained within the area considered are shown from Figures 3 to 12 
Journal DOI: 10.46654/ij.24889849

Vol. 6, Issue 10 (October, 2020) | www.ijaar.org

Article DOI: 10.46654/ij.24889849.e61011

\subsection{Results and Discussion}

Table 1: Ignition frequency $I_{F}$

\begin{tabular}{|c|c|c|c|c|c|}
\hline $\begin{array}{c}\text { Building } \\
\text { Class }\end{array}$ & $\alpha_{1}$ & $\alpha_{2} \exp (-6)$ & $\mathrm{P}$ & $\mathrm{Q}$ & $\begin{array}{c}\text { Ignition } \\
\text { frequency } I_{F}\end{array}$ \\
\hline $\begin{array}{c}\text { Residential } \\
\text { structures }\end{array}$ & 0.050 & 6 & -1.73 & -0.04 & 179.3317 \\
\hline $\begin{array}{c}\text { Commercial } \\
\text { structures }\end{array}$ & $8 \exp (-5)$ & 7 & -0.65 & -0.04 & 7.851011 \\
\hline $\begin{array}{c}\text { Office } \\
\text { structures }\end{array}$ & 0.067 & 4 & -2.10 & -0.04 & 293.1086 \\
\hline $\begin{array}{c}\text { Hospital } \\
\text { structures }\end{array}$ & $8 \exp (-5)$ & 2 & -0.56 & -0.04 & 6.368576 \\
\hline $\begin{array}{c}\text { School } \\
\text { structures }\end{array}$ & $3 \exp (-4)$ & 6 & -1.34 & -0.04 & 49.98963 \\
\hline $\begin{array}{c}\text { Industrial } \\
\text { structures }\end{array}$ & 0.0045 & 3 & -1.45 & -0.04 & 2529.594 \\
\hline Warehouses & $4 \exp (-5)$ & 4 & -2.30 & -0.04 & 4071.71 \\
\hline $\begin{array}{c}\text { Other } \\
\text { structures }\end{array}$ & 3.65 & 6 & -2.18 & -0.04 & 1.242783 \\
\hline $\begin{array}{c}\text { Prison } \\
\text { structures }\end{array}$ & 1.25 & 100 & -1.89 & -0.03 & 1.698636 \\
\hline
\end{tabular}

Table 1 shows the ignition frequency as obtained in the building structures considered using Equation (5) and data obtained within the area. Industrial buildings and warehouses are the leading structures with ignition frequencies with 4071.71 and 2529.954 respectively while other structures and prison structures form the least with 1.242783 and 1.698636 respectively. Interviews with professionals and employees show that industrial buildings tend to experience most fire incidences which corroborate the results obtained in this study. According to the interviewers, this high ignition frequency in industrial buildings is predominantly due to lack of adequate fire suppression system in place. 
Table 2: Fire extinguisher performance

\begin{tabular}{|c|c|c|c|}
\hline Building Class & $\begin{array}{c}\text { Dependability of } \\
\text { activation (\%) }\end{array}$ & $\begin{array}{c}\text { Efficiency of } \\
\text { suppression (\%) }\end{array}$ & $\begin{array}{c}\text { Probability of } \\
\text { suppression (\%) }\end{array}$ \\
\hline Factories & 38 & 35 & 13.3 \\
\hline Electrical workshops & 45 & 40 & 18 \\
\hline $\begin{array}{c}\text { Two bedroom blocks } \\
\text { of flat }\end{array}$ & 39 & 43 & 21.1 \\
\hline $\begin{array}{c}\text { Welding workshops } \\
\text { Hotels }\end{array}$ & 49 & 57 & 33.1 \\
\hline Open markets & 58 & 35 & 14.4 \\
\hline Oil spillage terrain & 37 & 36 & 13.3 \\
\hline Government offices & 47 & 49 & 23 \\
\hline Bungalows & 50 & 52 & 26 \\
\hline
\end{tabular}

Table 2 shows the probability of fire suppression which is the product of dependability of activation and efficiency of suppression. Open market and oil spillage terrain produced the least in terms of success in fire suppression with 14.4 and 13.3 respectively while bungalows and hotels produced the lowest with 26 and 33.1. The low suppression rate obtained in open markets and oil spillage could be attributed to inadequate or ineffective suppression systems in such places. 


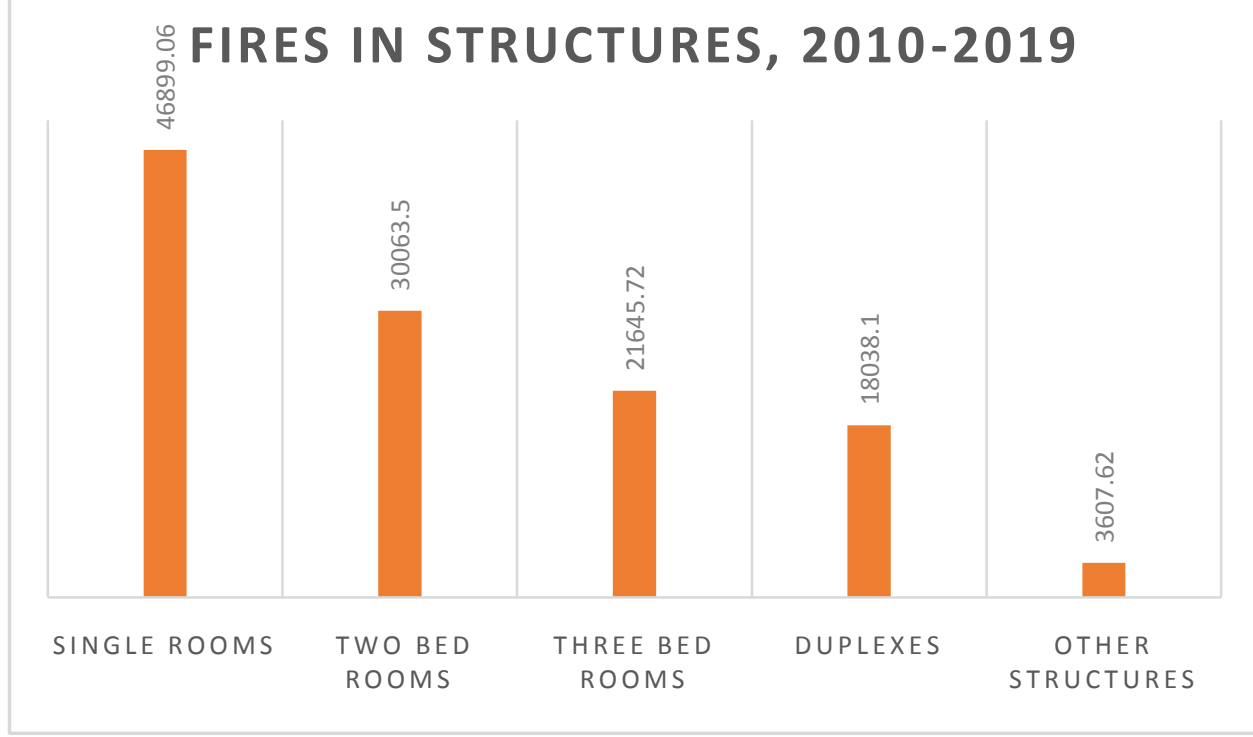

Figure 3: Fires in structures

Figure 3 shows data obtained for fires in structures from 2010 to 2019. As obtained in the Figure, single rooms were seen to be most affected with 46899.06 occurrences while other structures remain the least with 3607.62 occurrences. This high occurrence in single rooms is due to constraints of occupants not being able to afford suppression system.

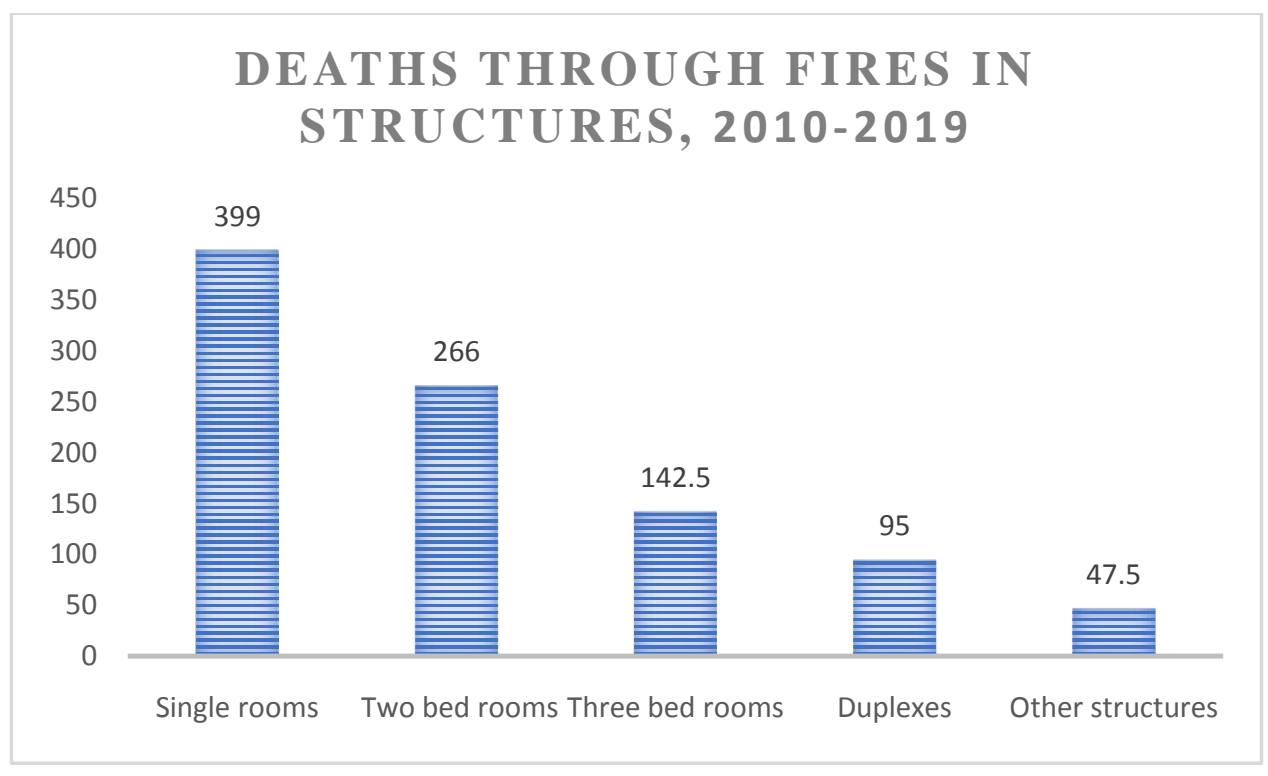

Figure 4: Deaths through fires in structures

Figure 4 shows data obtained for deaths through fires in structures from 2010 to 2019. As obtained in the Figure, single rooms recorded the most fatalities with 399 occurrences while other structures remain the least with 47.5 occurrences. The deaths recorded in single rooms form about $42 \%$ of all deaths experienced in the period of consideration. 


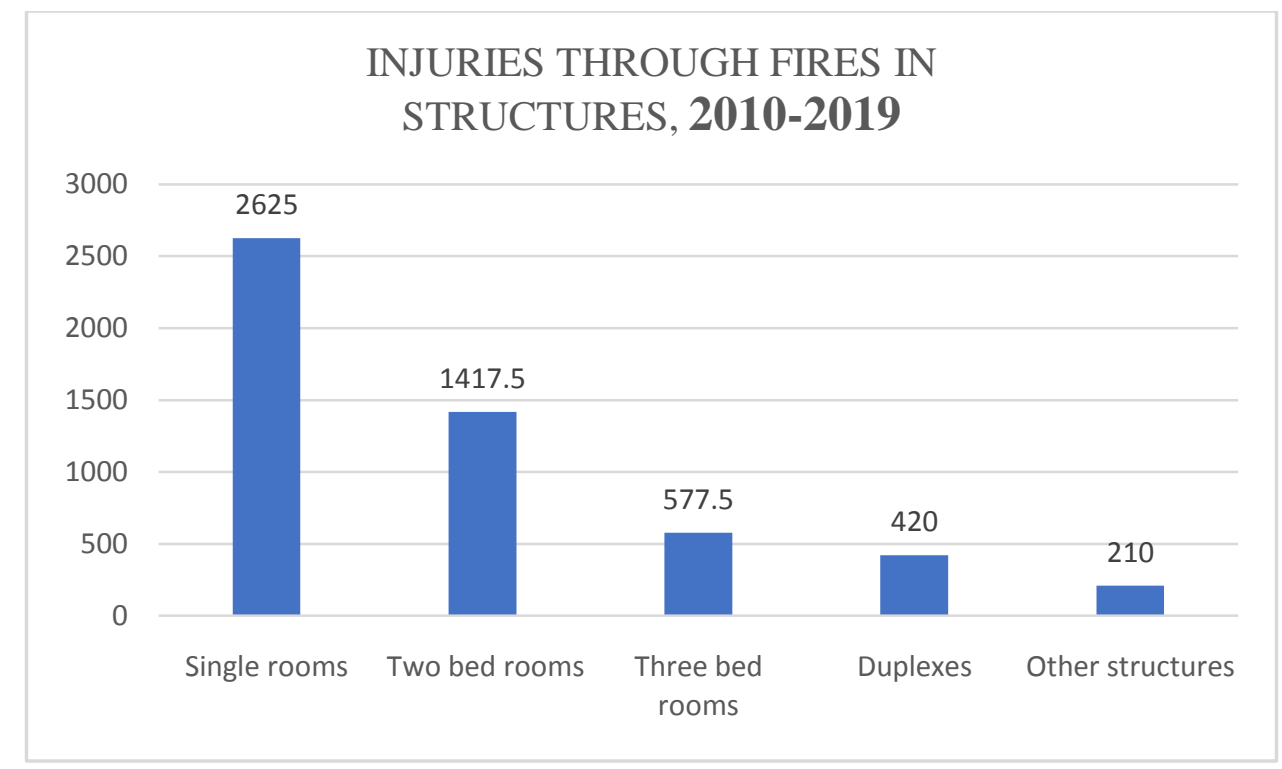

Figure 5: Injuries through fires in structures

Figure 5 shows data obtained for injuries through fires in structures from 2010 to 2019. As obtained in the Figure, single rooms recorded the most injuries with 2625 occurrences while other structures remain the least with 210 occurrences. The deaths recorded in single rooms form about $50 \%$ of all injuries experienced in the period of consideration.

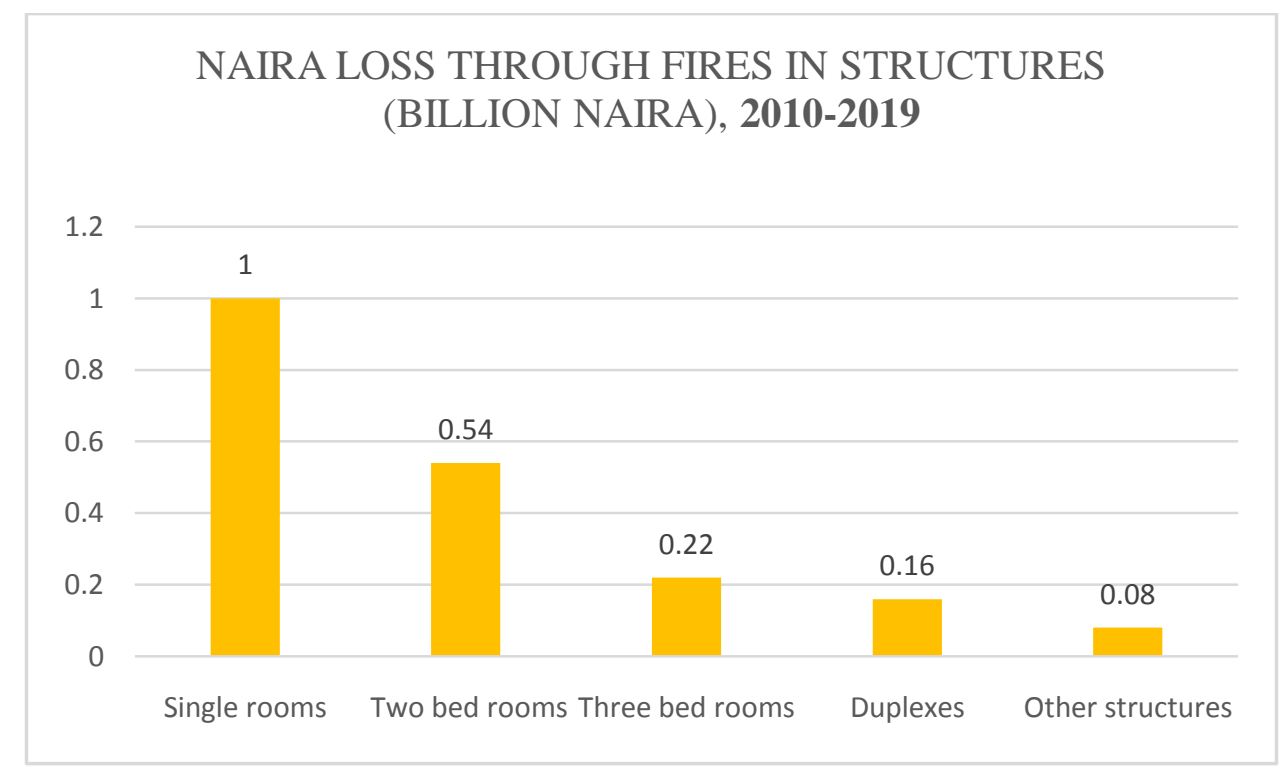

Figure 6: Naira loss through fires in structures 
Journal DOI: 10.46654/ij.24889849

Vol. 6, Issue 10 (October, 2020) | www.ijaar.org

Article DOI: 10.46654/ij.24889849.e61011

Figure 6 shows data obtained for Naira loss through fires in structures from 2010 to 2019. As obtained in the Figure, single rooms recorded the most Naira loss 1 1billion while other structures remain the least with $\$ 0.08$ billion .The loss in money recorded in single rooms, forms about $50 \%$ of all money lost in the period of consideration.

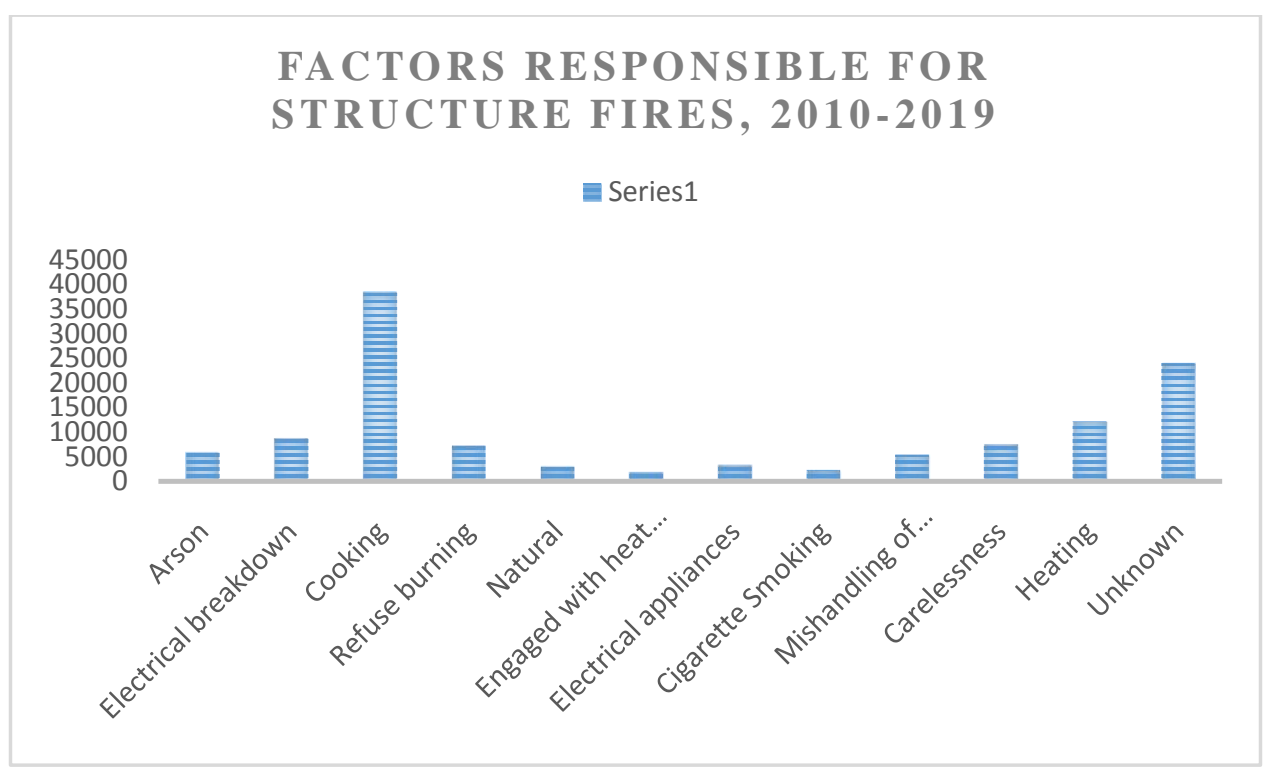

Figure 7: Factors responsible for fires in structures

Figure 7 shows data obtained for factors responsible for fires in structures from 2010 to 2019. As obtained in the Figure, cooking, heating, and electrical breakdown and carelessness remain the leading causes of fires in structures within the region while natural and cigarette smoking are the least factors. 


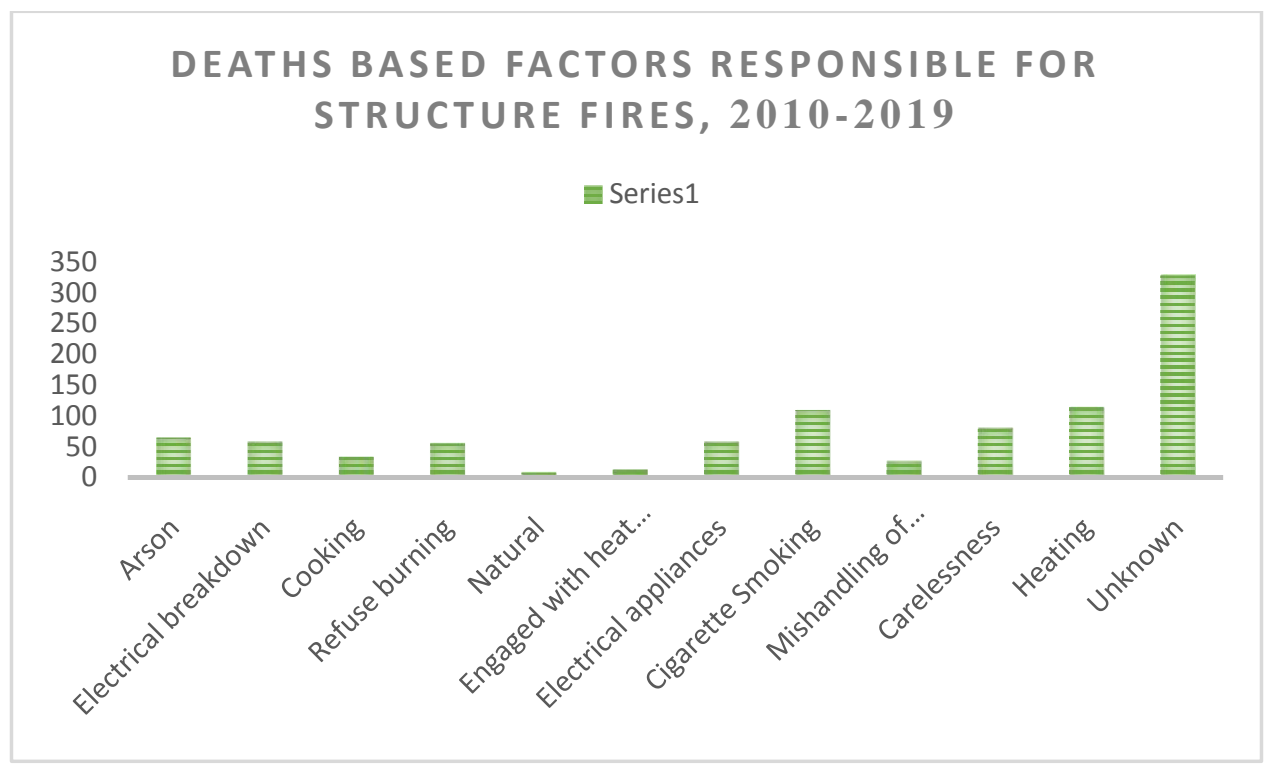

Figure 8: Deaths based factors for fires in structures

Figure 8 shows data obtained for death based factors for fires in structures from 2010 to 2019. It was gathered from data obtained that, unknown factors, cigarette smoking, and heating form the major factors of deaths in a fire outbreak. The least factors recorded are natural means, mishandling of equipment, and engaging with heat sources.

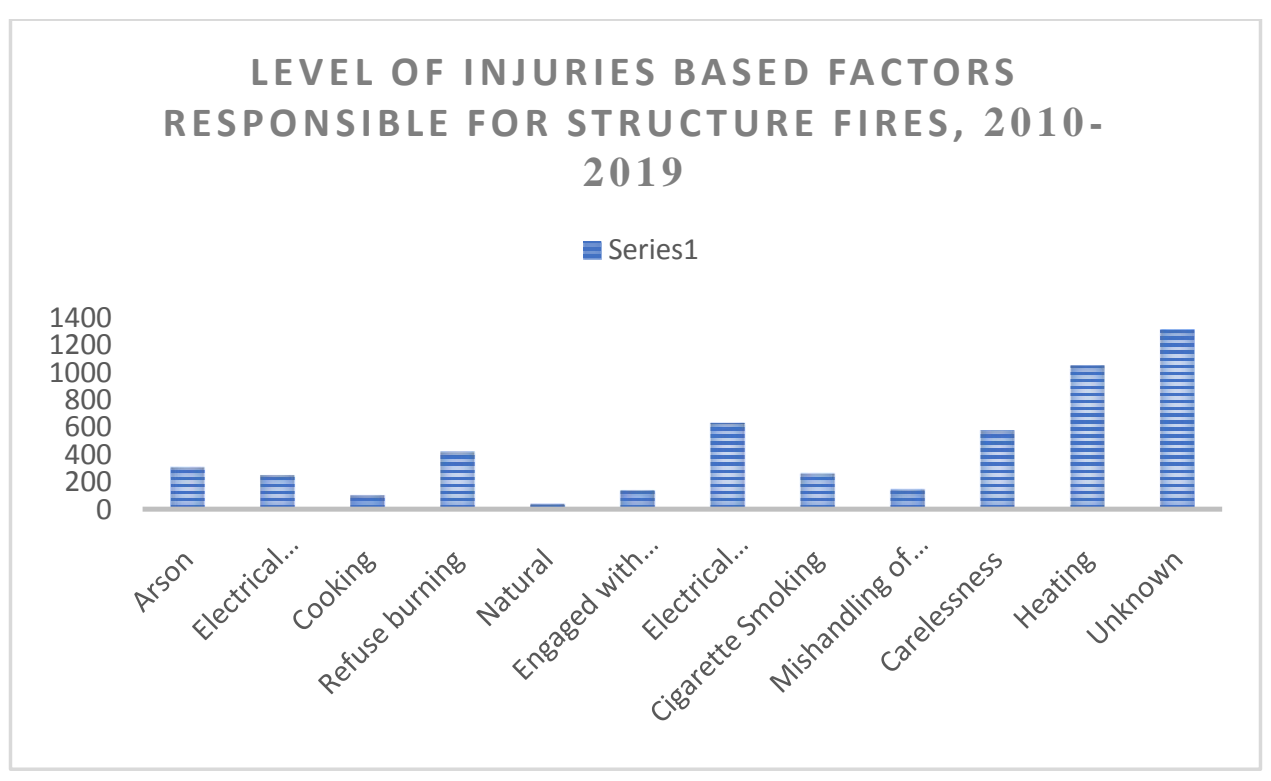

Figure 9: Level of injuries based factors for fires in residential and commercial structures

Figure 9 shows level of injuries based factors for fires in residential and commercial structures from 2010 to 2019. It was gathered from data obtained that, the main injuries recorded within the region are unknown factors, heating, electrical faults, and carelessness. The least factors recorded are natural means, cooking, and engaging with heat sources. 


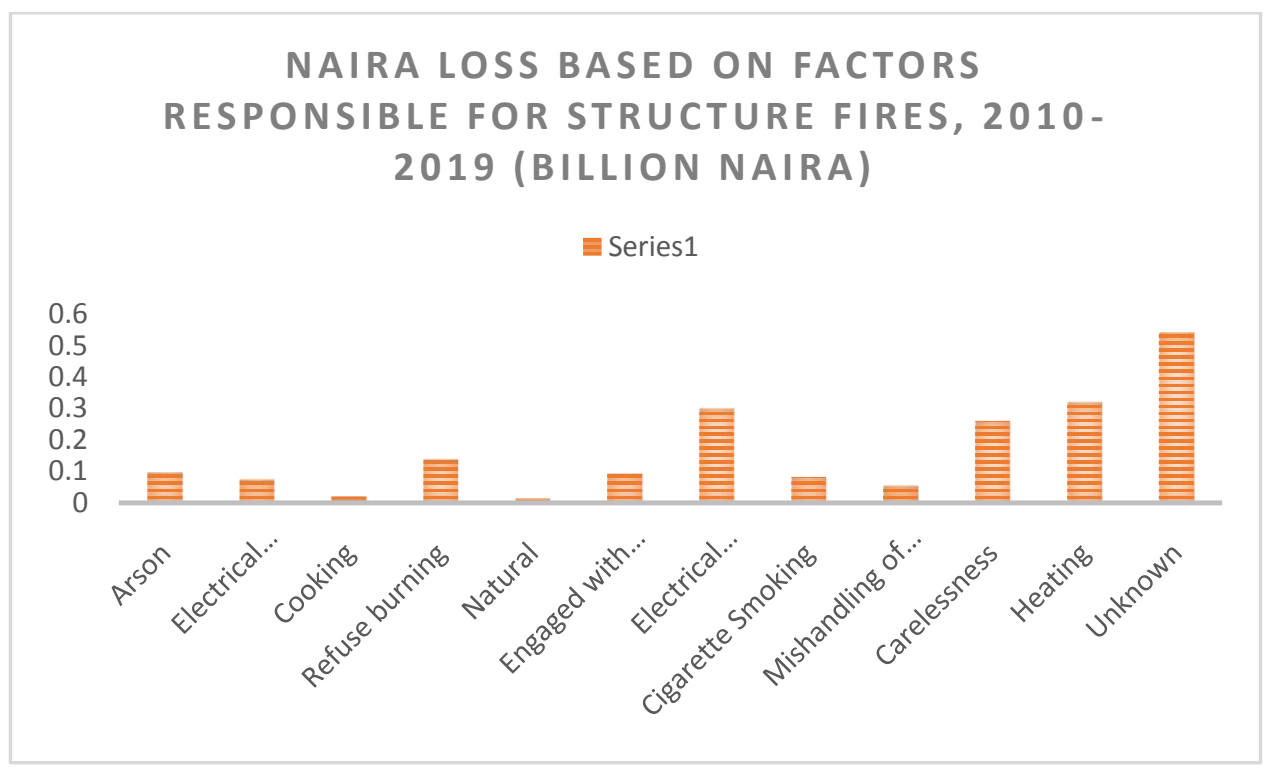

Figure 10: Naira loss based factors for fires structures

Figure 10 shows Naira loss based factors for fires in residential and commercial structures from 2010 to 2019. Unknown factors, heating, electrical faults, and carelessness were recorded as the leading factors while natural means, cooking, and mishandling of equipment were recorded as the least.

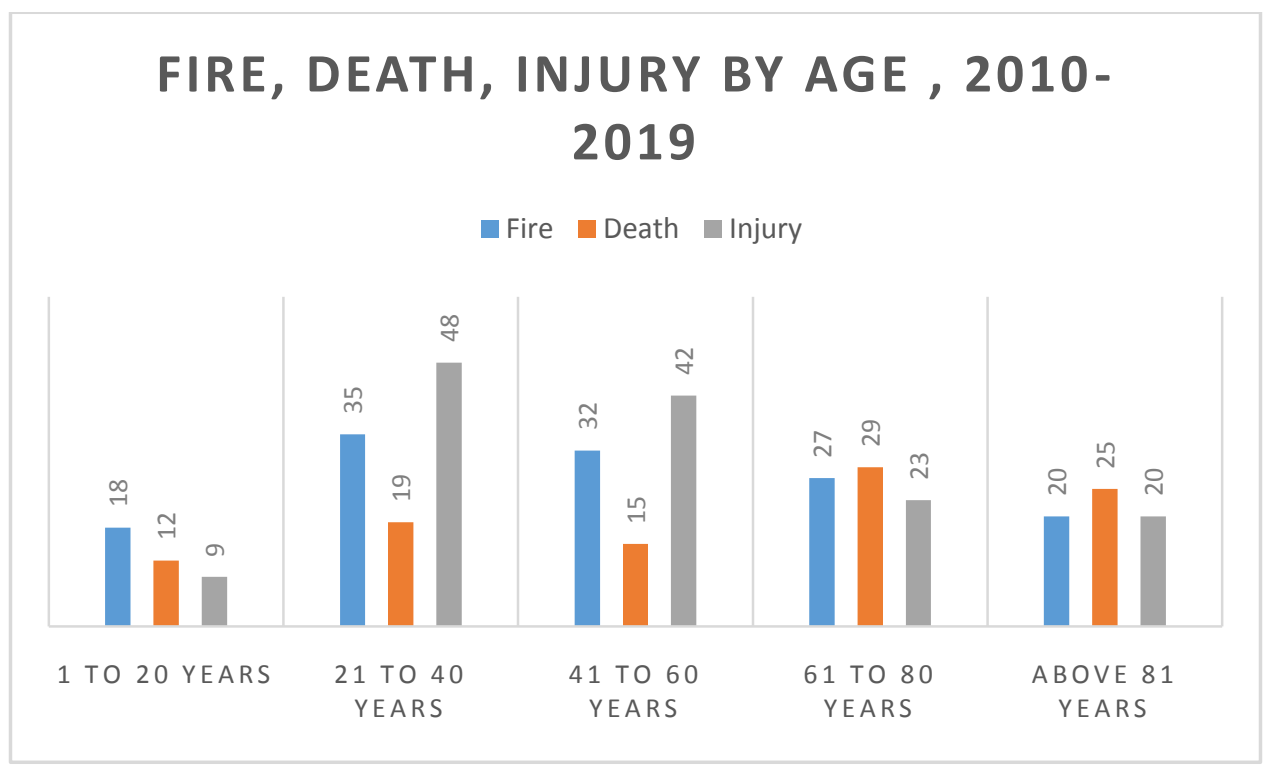

Figure 11: Fire, death, injury by age 
Figure 11 shows fire, death, and injury by age for fires in residential and commercial structures from 2010 to 2019. Victims within the age of 21 to 60 were mostly affected in structure fires. This was due to the fact that majority of the workforce of commercial structures are within the age range.

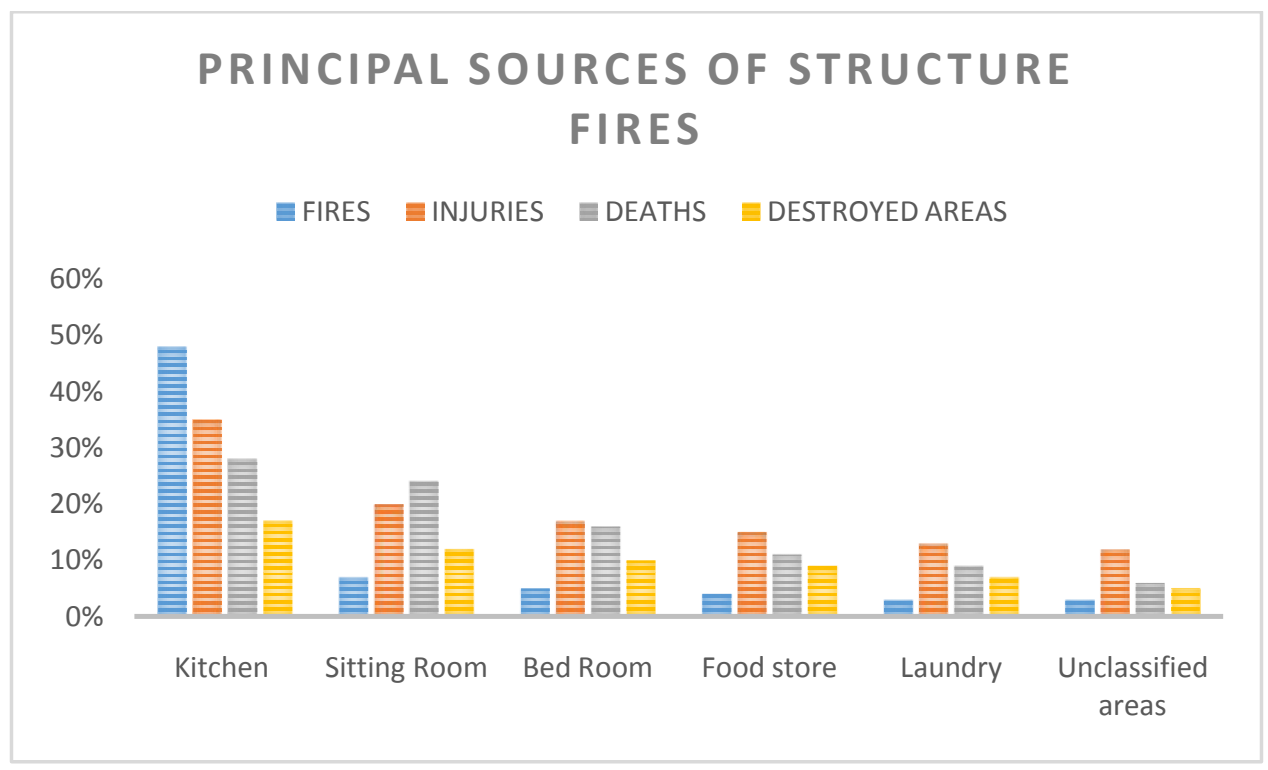

Figure 12: Principal sources of structure fires

Figure 12 shows data obtained for principal sourcesoffires in structures from 2010 to 2019. For most residential structures, the kitchen emerged as the leading source of fires while the least is unclassified. It therefore suggests that majority of fires in residential fires could be abated if adequate attention and priority is given to fires through kitchen

\subsection{Recommendations}

To curb and minimize the cases of fire disaster in structures in Nigeria, the following recommendations should be considered by all occupants while relevant authorities should enforce them as much as possible:

- The process of building construction from foundation to roofing should be carried out strictly by professionals in the built industry and not quacks

- Quality of electrical materials should be employed in constructions and well monitored by relevant authorities to ascertain if it conform to standard.

- Every builder or contractor should ensure less combustible materials are employed for their construction, as itserves as fire resistances in case there is an outbreak.

- Automatic smoke detectors should be adopted by all and sundry. Regular checks should be done by relevant authorities to ascertain compliance.

- The standard organization of Nigeria (SON), should enforce the usage of standard materials for building construction.

- The fire service department should be well-equipped with up to date equipment and facilities to put out fire cases within the shortest minimum time. 
Journal DOI: 10.46654/ij.24889849

Vol. 6, Issue 10 (October, 2020) | www.ijaar.org

\subsection{Conclusion}

This study provides an elaborate research analysis into cases of structure fires in the South-east region from 2010 to 2019. Data were obtained from firefighting agencies within the region. Various causes of fires in homes, offices, industries, were highlighted. Models were developed to ascertain ignition frequencies, fire suppression probabilities, and dependability of fire extinguishers activation. The entire study provides a base line information on fire situations within the region especially for commercial and residential structures.

\section{ACKNOWLEDGEMENTS}

The authors are truly grateful to GOD almighty for his infinite grace, mercy and favour all through the course of this novel engineering research feat. Also, our sincere appreciation goes to everyone who contributed in one way or the other to the success of this research project. Moreover, for your inestimable support, we the authors humbly wish to say a -big THANK YOU to the staff and management of the Nigerian Building and Road Research Institute (NBRRI) — an agency under Nigeria's Federal Ministry of Science and Technology, based in Abuja, Nigeria. 


\section{References}

1. Fire Service Bureau, Ministry of Public Security, China fire services, China Personnel Press, Beijing, 2012 (in Chinese).

2. Adekunle A., Arowolo T.A., Adeyemi O.M.,Kolawole O.A (2020) Estimation of Thermal Comfort Parameters of Building Occupants Based on Comfort Index, Predicted Mean Vote, and Predicted Percent of Dissatisfied people in the North-Western Zone of Nigeria (IJAEM,E-ISSN: 2395-5252, Vol. 2 Issue 5, September 2020, DOI: http://doi.org/10.35629/5252-0205809820)

3. Fire Service Bureau, Ministry of Public Security, China fire services, International Cultural Publishing Company, Beijing, 2011 (in Chinese).

4. Adekunle A., Osagie Ibhadode, A.P Ibhadode and Shawon Msughter Caesar (2020) Assessment of Carbon Emissions for the Construction of Buildings Using Life Cycle Analysis: Case Study of Lagos State (IJERAT,E-ISSN: 2454-6135, Vol. 6 Issue 8, August 2020, DOI: http://doi.org/10.31695/IJERAT.2020.3628 )

5. Fire Service Bureau, Ministry of Public Security, China fire services, International Cultural Publishing Company, Beijing, 2010 (in Chinese).

6. Adekunle A. and Gbenga-Ilori A. (2020), Minimizing Interference in Ultra-Dense Femtocell Networks Using Graph-Based Frequency Reuse Technique, FUOYE Journal of Engineering and Technology (FUOYEJET) http://engineering.fuoye.edu.ng/journal/index.php/engineer/article/view/456.

7. Fire Service Bureau, Ministry of Public Security, China fire services, China Personnel Press, Beijing, 2009 (in Chinese).

8. Osagie Ibhadode, A.A. Adekunle, Solomon O. Banjo, O.D. Atakpu (2020). Thermophysical, Electrical and Mechanical Characterizations of Normal and Special Concretes: A Holistic-Empirical Investigation for Pre-qualification and Quality-Control of Concrete (Journal of Physics Conference Series. DOI:http://doi.org/10.1088/17426596/1378/4/042100.

9. Fire Service Bureau, Ministry of Public Security, China fire services, China Personnel Press, Beijing, 2008 (in Chinese).

10. Osagie Ibhadode, A. Adekunle, C. O. Nwafor, I. I. Umanah (2020).Interference Mitigation Among Indoor Phone Subscribers In LTE Based Heterogeneous Networks Using Fast Response Frequency Reuse Technique (Journal of Physics Conference Series. DOI: http://doi.org/10.1088/1742-6596/1378/3/032019 )

11. Grant Purdy, ISO 31000:2009 - Setting a new standard for risk management, Risk Analysis, vol. 30, 2010, pp. 881-892.

12. Osagie Ibhadode, A. Adekunle, Joseph Azeta, Y. K. Abimiku (2020). An Investigation of the Influence Of Femtocells Network On A Small Size Indoor Environment Using ITU-R And Winner II Path Loss Models (Journal of Physics Conference SeriesDOI: http://doi.org/10.1088/1742-6596/1378/3/032020 )

13. ISO 31000, Current draft vocabulary for risk management - ISO/IEC Guide 73:2009, 2002. [8] S.I. Suddle, Physical safety in multiple use of space, Ph.D. Dissertation, Delft University of Technology, Print Partners Ipskamp, ISBN 90-808205-2-0, 2004. 
14. Adekunle A., Asaolu G.O., Adiji K., Kasheem Umar A (2019) Improvement of Channel Capacity in a Multiple Input Multiple Output LTE Radio System for GSM-Users Using Ideal Power Distribution Technique. (IJASRE, E-ISSN: 2454-8006, Vol.5 Issue 9, September 2019, DOI: http://doi.org/10.31695/IJASRE.2019.33494)

15. A.M. Hasofer, V.R. Beck, I.D. Bennetts, Risk Analysis in Building Fire Safety Engineering, first ed., Butterworth-Heinemann, London, 2006. (Chapter 1 MA).

16. Osagie Ibhadode, Oluseyi Olarenwaju Ajayi, Abiodun Ayodeji Abioye, Joseph Ismaila, Adebayo Abidemi Adekunle (2019). An evaluation of classroom illumination: A critical requirement for effective designing and construction of naturally-illuminated schools in Nigeria. Progress in Industrial Ecology, an International Journal Vol. 13, Issue. 4, Pages. 342-372, DOI: http://doi.org/10.1504/PIE.2019.102849)

17. T. Bedford, R.M. Cooke, Probabilistic Risk Analysis: Foundations and Methods, Cambridge University Press, 2001.

18. D. Yung, N. Benichou, How design fires can be used in fire hazard analysis, Fire Technology 38 (3) (2002) 231-242.

19. Osagie Ibhadode, A. Adekunle, Y. K. Abimiku, N. M. Umeobika. (2019). Noise-level Characterization of Portable Electric-power Generators in North-Central Nigeria: A Brand-by-Brand Comparative-study (IJERAT,E-ISSN: 2454-6135, Vol.5 Issue 4, April 2019, DOI: http://doi.org/10.31695/IJERAT.2019.3427)

20. Adekunle A.; Adewale A.K.; Olaifa O.A; Ukoh S.N.B. (2019).Statistical Study on Types, Causes, Effects and Remedies of Corrupt Practices in Construction Industries in Nigeria (IJASRE, E-ISSN: 2454-8006, Vol.5 Issue 4, April 2019, DOI: http://doi.org/10.31695/IJASRE.2019.33493)

21. Adekunle A., Nwaigwe D.N., Nya Essang, Samuel P.O. (2019) Application of road transportation system to generate electricity via road humps in Lagos State Nigeria.(IJASRE, E-ISSN: 2454-8006, Vol.5 Issue 4, April 2019, DOI: http://doi.org/10.31695/IJASRE.2019.32993)

22. Adekunle A., Abimiku Y.K., Umeobika N.M., Ameh E.E (2018). Radio wave detection using cost 231-Hata model for wireless network planning; a case study of senate building environs of Unilag, Nigeria.(IJASRE, E-ISSN: 2454-8006, Vol.4 Issue 12, December 2018, DOI: http://doi.org/10.31695/IJASRE.2018.32992)

23. Adekunle A., Umanah I.I., Adewale A.K., Egege C.C (2018). Analytical study of casualties in the construction industry in Nigeria with a view to provide remedial measures: case study of Lagos state. (IJERAT,E-ISSN: 2454-6135, Vol.4 Issue 8, August 2018, DOI: http://doi.org/10.31695/IJERAT.2018.3293)

24. FIRECAM, Fire risk evaluation and cost assessment model, National Research Council Canada, 2008, 〈http://irc.nrc-cnrc.gc.ca/fr/frhb/firecamnewe.html $\rangle$.

25. N. Benichou, A.H. Kashef, I. Reid, et al., FIERAsystem: a fire risk assessment tool to evaluate fire safety in industrial buildings and large spaces, Journal of Fire Protection Engineering 15 (2005) 145-172.

26. Adekunle A., Umanah I.I., Ibe K.E., Imonikosaye M. Rukewe (2018). Statistical Analysis of Fire Outbreaks in Homes and Public Buildings in Nigeria: A Case Study of Lagos State (IJERAT, E-ISSN:2454-6135, Vol.4 Issue 8, August 2018, DOI: http://doi.org/10.31695/IJERAT.2018.3294) 
27. Adekunle A., Asaolu G.O., Adiji K., Bamiduro H.A (2016). Impacts of electrical hazards on Nigerian construction industries with a view to provide safety measures(JSDS,ISSN 2201-4268, Vol.9, Number 2,2016,267-289 https://infinitypress.info/index.php/jsds/article/download/1365/612)

28. A. Adekunle, A. Asuquo, N. Essang, I.I.Umanah, K.E. Ibe, Ayo Bamidele Alo (2016). Statistical analysis of electrical fire outbreaks in buildings: case study of Lagos state, Nigeria(JSDS,ISSN2201-4268,Vol.9,Number1,2016,76-92 https://infinitypress.info/index.php/jsds/article/view/1288)

29. Adekunle A., Ibe K.E., Kpanaki M.E., Umanah I.I., Nwafor C.O., Essang N (2015). Evaluating the effects of radiation from cell towers and high tension power lines on inhabitants of buildings in Ota, Ogun state (JSDS,ISSN 2201-7372, Vol.3, Number 1, 2015, 1-21 https://www.infinitypress.info/index.php/cas/article/download/872/494)

30. Adekunle A., Abimiku Y.K., Nwafor C.O., Nwaigwe D.N., Agbonkhese O (2015). High Voltage Transformers and Electromagnetic Emissions. (IISTE, ISSN 2225-0638, Vol.46,2015,16-25 https://iiste.org/Journals/index.php/APTA/article/download/24614/25216)

31. G.H. Kristiansson, On Probabilistic Assessment of Life Safety in Building on Fire, Report 5006, Department of Fire Safety Engineering, Lund University, Lund, Sweden, 1997.

32. J.K. Vrijling, W. van Hengel, R.J. Houben, Acceptable risk as a basis for design, Reliability Engineering and System Safety 59 (1998) 141-150.

33. N. Benichou, D. Yung, G.V. Hadjisophocleous, Impact of fire department response and mandatory sprinkler protection on life risks in residential communities, in: Proceedings of the 8th International Fire Science and Engineering Conference, Interflam '99, Edinburgh, Scotland, 1999, pp. 521-532.

34. A.Adekunle, E.S.Ekandem, K.E. Ibe, G.N.Ananso, E.B.Mondigha (2014). Analysis of thermal and electrical properties of Laterite, clay and sand samples and their effects on inhabited buildings in Ota, Ogun state, Nigeria. (JSDS,ISSN 2201-4268, Vol.6,Number 2,2014,391-412 https://infinitypress.info/index.php/jsds/article/download/799/378)

35. Ekandem E.S., Daudu P.I., Lamidi R.B., Ayegba M.O., Adekunle Adebayo (2014). Spontaneous Settlements: Roles and Challenges to Urban Planning. Journal of Sustainable Development. (JSDS,ISSN 2201-4268, Vol.6, Number 2, 2014, 361-390 https://infinitypress.info/index.php/jsds/article/view/760)

36. Agbonkhese O., Agbonkhese E.G., Aka E.O., Joe-Abaya J., Ocholi M., Adekunle A. (2014).Flood menace in Nigeria: impacts, remedial and management strategies. (IISTE, ISSN

2225-0514,Vol.6,Number4,2014,32-40 https://www.iiste.org/Journals/index.php/CER/article/download/12140/12492)

37. D. Yung, G.V. Hadjisophocleous, B. Yager, Case study: the use of FIRECAM to identify cost-effective fire safety design options for a large 40-storey office building, in: Proceedings of the Pacific Rim Conference and 2nd International Conference on Performance-Based Codes and Fire Safety Design Methods, 1998, pp. 441-452.

38. U.U.Ndubuisi-Nnaji, A.O.Inyang-Enin, U.A.Ofon and OsagieIbhadode (2020): Metagenomic Study of Bacterial and Archaeal Populations during Anaerobic Digestion of Lignocellulosic Wate in Lab-scale Biogas Reactors. European Journal of Biology and Biotechnology, 1(5), 1-10. DOI:10.24018/ejbio.2020.1.5.75 
39. K.M. Elovitz, Commissioning smoke control systems, Fire Protection Engineering Magazine, Society of Fire Protection Engineers, Bethesda, MD, 2006, pp. 28-40.

40. OsagieIbhadode, S.A.B. Fiyebo, C.C. Egege, M.C. Ugonna (2020): City-wide Quality Assessment of Sandcrete Mansory Blocks Produced in Lagos, Ibadan and Abeokuta Metropolitan-cities in South-western Nigeria, International Journal of Advances in Scientific Research and Engineering, 6(8), 56-73.DOI:10.31695/IJASRE.2020.33856

41. Daniela Hanea, Ben Ale, Risk of human fatality in building fires: a decision tool using Bayesian networks, Fire Safety Journal 44 (2009) 704-710.

42. J.M. Watts, J.R. Hall, Introduction to Fire Risk Analysis, SFPE Handbook for Fire Protection Engineering, third ed., NFPA, Quincy, MA, 2002. 